\title{
Wartości i interesy a prawo pracy - tytułem wstępu
}

1. Treścią funkcji ochronnej prawa pracy, od jego narodzin, zawsze była ochrona pracowników (osób podejmujących zatrudnienie w celu pozyskania środków utrzymania). W ramach prawa pracy rozwijały się zatem instytucje prawne, których dążeniem była efektywna ochrona pracowników przed różnorodnymi zagrożeniami występującymi w związku z zatrudnieniem. Z natury rzeczy głównym celem tych regulacji jest tworzenie narzędzi eliminujących określone niebezpieczeństwa lub ograniczających ich skutki. Przykładem takich konstrukcji jest instytucja ochrony wynagrodzenia za pracę, która ma zapewnić wypłatę wynagrodzenia w określonej (godziwej) wysokości, w ustalonym terminie i formie. Inny przykład to regulacje, których zadaniem jest ochrona trwałości stosunku pracy - w tym przypadku chodzi o jak najdłuższe zachowanie stanowiska pracy u określonego pracodawcy. Przykłady te można wskazywać bez końca, gdyż każda niemal instytucja prawa pracy służy realizacji wskazanej powyżej funkcji'.

Występujące obecnie na świecie zjawiska społeczne i ekonomiczne, jak w szczególności globalizacja oraz dotykający wielu krajów kryzys gospodarczy, bardzo silnie oddziałują na stosunki zatrudnienia, a przy tym również na treść przepisów prawa. Dążenie do ograniczenia ich negatywnych konsekwencji prowadzi często do kontestowania uprawnień pracowniczych, gwarantowanych przez prawo pracy. W efekcie powoduje to również ograniczanie tych uprawnień, odbieranie pracownikom praw zdobytych w okresach koniunktur gospodarczych na przestrzeni ostatnich dwóch stuleci².

* Prof. nadzw. dr hab. MiRosŁaW WŁodarczYk, Katedra Prawa Ubezpieczeń Społecznych i Polityki Społecznej, Katedra Prawa Pracy, Wydział Prawa i Administracji, Uniwersytet Łódzki, 90-232 Łódź, ul. Kopcińskiego 8/12.

${ }^{1} \mathrm{Na}$ ten temat patrz np.: J. JoŃczYK, Ochrona pracy kobiet i młodocianych w polskim przemyśle w latach 1918-1939, Warszawa 1961; W. SzuBert, Ochrona pracy, Warszawa 1966; idem, Funkcje prawa pracy, „Państwo i Prawo” 1971, nr 3-4; L. FLOREK, Ochrona praw i interesów pracownika, Warszawa 1990; M. SKĄSKI, Ochronna funkcja prawa pracy w gospodarce rynkowej, Zakamycze 2006.

2 Kwestie te od dawna są przedmiotem zainteresowania doktryny prawa pracy; patrz np.: T. ZiELIŃSkI, Problemy rozwoju prawa pracy, Materiały VII Ogólnopolskiego Zjazdu Katedr (Zakładów) Prawa 
Obniżanie standardów ochrony pracowników następuje zawsze w przypadku pojawienia się dekoniunktury gospodarczej. Zanim proces globalizacji gospodarki światowej przybrał obecną postać (do lat siedemdziesiątych ubiegłego wieku) kryzysy uderzały w pracowników głównie poprzez obniżanie wysokości płac oraz ograniczanie rozmiarów zatrudnienia (wzrost bezrobocia). Fenomen globalizacji zmienił zasadniczo warunki funkcjonowania gospodarek krajów europejskich - wysokie koszty zatrudnienia powodują, że przegrywają one w konkurencji z rozwijającymi się krajami Azji (Korea, Chiny, Indie). Jako przyczynę owej mniejszej konkurencyjności wskazuje się bardzo często istnienie rozwiniętych uprawnień socjalnych pracowników oraz brak elastyczności prawa pracy. Atak na ochronne instytucje prawa pracy został rozpoczęty już niemal trzydzieści lat temu - a więc w okresie, kiedy globalizacja postrzegana była optymistycznie, jako podstawowy motor rozwoju gospodarki światowej. Na wywołaną przez globalizację tendencję do uelastycznienia prawa pracy nałożył się obecny kryzys gospodarczy, który bez wątpienia wzmaga i wspiera wskazaną tendencję do ograniczania uprawnień pracowniczych ${ }^{3}$.

Proces deregulacji prawa pracy (lub - ujmując to bardziej oględnie - zwiększania jego elastyczności), który trwa już od trzydziestu co najmniej lat, nie został więc wywołany przez obecny kryzys gospodarczy. Z punktu widzenia zaś postawionych dalej kwestii istotne jest, że podstawowym kryterium dokonywania zmian w prawie pracy jest owa konkurencyjność gospodarki - w praktyce oznacza to, że zmiany dyktowane są przez potrzeby przedsiębiorców dążących do poprawienia pozycji rynkowej swych firm w skali międzynarodowej. W tym kontekście ocenia się ogólne koszty pracy ludzkiej w relacji do takich kosztów występujących w innych krajach i - by te ciężary obniżyć - niekiedy wskazuje się ograniczanie uprawnień pracowniczych jako jedyny sposób osiągnięcia tego celu. W pierwszej kolejności ma temu służyć dopuszczalność stosowania tzw. elastycznych form zatrudnienia, tańszych (a więc konkurencyjnych) w porównaniu do klasycznej bezterminowej umowy o pracę. Preferuje się zatem stosowanie terminowych umów o pracę oraz umów prawa cywilnego (umowa zlecenie, umowa o dzieło, samozatrudnienie). W konsekwencji prowadzi to do ograniczenia, a w dalszej kolejności do pozbawienia osób zatrudnionych w tych formach ciągłości i trwałości

Pracy, Kraków 1984; Studia z prawa pracy. Dla uczczenia 50-lecia działalności naukowej Profesora Wacława Szuberta, red. H. Lewandowski, Warszawa-Łódź 1988; Polskie prawo pracy w okresie transformacji w oświetleniu prawa wspólnotowego, red. H. Lewandowski, Warszawa 1997; Prawo pracy u progu XXI wieku. Stare problemy i wyzwania współczesności, Materiały z XIII Ogólnopolskiego Zjazdu Katedr i Zakładów Prawa Pracy, Białystok 2001; Prawo pracy a wyzwania XXI-go wieku, Księga jubileuszowa Profesora Tadeusza Zielińskiego, Warszawa 2002; Granice liberalizacji prawa pracy. Problemy zabezpieczenia społecznego, Materiały z XIV Zjazdu Katedr (Zakładów) Prawa Pracy i Ubezpieczeń Społecznych, red. E. Bielak, H. Lewandowski, Łódź 2003; Układy zbiorowe pracy. W stulecie urodzin Profesora Wacława Szuberta, red. Z. Góral, Warszawa 2013.

${ }^{3}$ Patrz np.: M. Seweryński, R. Blanpain, A. Supiot, P. L. Davies, [w:] Referaty na VI Europejski Kongres Prawa Pracy i Zabezpieczenia Społecznego, Warszawa 1999; M. SKĄPSKI, op. cit., passim; M. Latos-Mıkowska, Ochrona interesu pracodawcy, Warszawa 2013. 
zatrudnienia, zaś w przypadku stosowania umów cywilnoprawnych - także do pozbawienia znacznej części uprawnień wynikających z zabezpieczenia społecznego. Innym przykładem jest stworzenie możliwości obniżania poziomu płac poprzez konstrukcje pozwalające na zawieszanie stosowania układów zbiorowych pracy, regulaminów wynagradzania czy warunków umów o pracę, a dalej poprzez dopuszczenie stosowania klauzul „opt-aut” oraz kształtowanie na niskim poziomie płacy minimalnej (lub nawet postulowanie odstąpienia od ustalania krajowej płacy minimalnej). W dziedzinie regulacji czasu pracy wskazać można wydłużanie okresów rozliczeniowych, zwiększanie limitów pracy w godzinach nadliczbowych czy szeroko stosowane zatrudnienie w niedziele i święta.

Wprowadzanie rozwiązań pozwalających na obniżanie kosztów pracy jest działaniem racjonalnym i uzasadnionym z punktu widzenia przedsiębiorcy-pracodawcy, zmierza bowiem bezpośrednio do podniesienia bieżącej konkurencyjności jego firmy. Decyzje prawodawcy determinowane są więc - co zostało już zaznaczone - interesem przedsiębiorców. Prowadzi to jednak do kolizji z interesami osób zatrudnionych; uprawnione wydaje się z punktu widzenia tych ostatnich oczekiwanie, że wskazane dążenie lobby gospodarczego zostanie skorygowane przez potrzebę ochrony interesów zatrudnionych - niestety w debatach, także naukowych, tego ostatniego wątku bardzo często brakuje.

Postawić trzeba zatem pytanie, jak daleko można się posuwać w ograniczaniu uprawnień pracowniczych, a nazywając rzecz inaczej - gdzie jest granica pomniejszania tych uprawnień. To jest także pytanie o racjonalność działań modyfikujących treść prawa pracy. Szukając odpowiedzi należy odwołać się do kategorii, która przez prawie dwieście lat determinowała rozwój prawa pracy i formowała jego treść - jest nią wskazana na początku tych uwag funkcja ochronna prawa pracy. Definiuje się ją zwykle jako działanie norm prawa pracy w sposób zabezpieczający interesy pracowników. Analiza norm prawa pracy, mająca na celu poszukiwanie przykładów działania tej funkcji, prowadzi z kolei do wniosku, że regulacje te tworzą instytucje i procedury, które ochronę taką mają zapewnić - brak w nich natomiast wskazania, o jakie interesy chodzi. Nazwanie owych interesów pozwoli ustalić, czy stworzone w prawie pracy środki ich ochrony są adekwatne do potrzeb, do charakteru i treści konkretnego interesu.

Jakie zatem okoliczności można uznać za owe interesy, chronione przez normy prawa pracy? Szukając odpowiedzi należy odwołać się do celu, jaki zamierza osiągnąć każda osoba podejmująca zatrudnienie. W pierwszej kolejności jest to wynagrodzenie, które chce ona przeznaczyć na pokrycie kosztów utrzymania siebie i rodziny. Podkreślić trzeba, że pracy nie podejmuje się w celu otrzymania jakiegokolwiek świadczenia, lecz po to, by uzyskać wartość majątkową, która tak określoną potrzebę (utrzymanie siebie i rodziny) zaspokoi - to jest granica wyznaczająca racjonalność zatrudnienia z punktu widzenia osoby zatrudnionej. Dalej zauważyć należy, że osobie świadczącej pracę zależeć będzie na zatrudnieniu trwałym - praca winna zapewnić stały dochód w długim horyzoncie czasowym, bo tylko 
wówczas będzie ona mogła realizować plany związane z życiem rodzinnym i osobistym, które zawsze są dalekosiężne. Wreszcie, trzeba odnieść się do zagrożeń, jakie wiążą się bezpośrednio z wykonywaniem określonej pracy - to przede wszystkim determinuje ochronę zdrowia: zarówno fizycznego (co objęte zostało ochroną już w najwcześniejszych regulacjach prawa pracy - przede wszystkim w przepisach dotyczących bezpieczeństwa i higieny pracy), jak i psychicznego (regulacje prawa pracy w tym zakresie zaczęły powstawać stosunkowo niedawno - dyskryminacja, molestowanie, mobbing). Z ochroną zdrowia ściśle związane jest też prawo do wypoczynku, gwarantowanego przez przepisy o minimalnym odpoczynku dobowym, tygodniowym i corocznym urlopie wypoczynkowym. Czas wolny to również czas niezbędny do realizacji planów osobistych czy wypełniania obowiązków rodzinnych.

Na powyższym wyliczeniu katalog owych interesów oczywiście się nie kończy. W rezultacie, szukając odpowiedzi na interesujące nas pytanie, należy odwołać się do kategorii, które przez szereg lat determinowały rozwój prawa pracy i kształtowały jego treść - są to wartości: życie, zdrowie, praca, godność, rodzina, sprawiedliwość społeczna czy równość, które były zawsze punktem odniesienia dla określania treści interesów pracowniczych.

W przedstawionym kontekście interesy pracownika zatem to szereg okoliczności i celów, które związane są z jego osobą lub życiem osobistym i rodzinnym, i dla których praca stanowi środek służący do ich realizacji. W ciągu niemal dwustu lat rozwoju prawa pracy pracownicy dążyli do takiego ukształtowania warunków zatrudnienia, by jak najlepiej służyło ono wypełnieniu wskazanych oczekiwań. Z pracowniczego punktu widzenia zmiana warunków zatrudnienia dopóty będzie racjonalna, dopóki określony interes pracowniczy pozostanie chroniony na społecznie akceptowalnym poziomie.

2. Przyjmowane w Polsce w ostatnich kilkunastu latach regulacje pokazują wyraźnie, czym kierował się prawodawca przy ich tworzeniu, jakie interesy zostały w tych wypadkach uwzględnione i w jakie wartości (dobra) ich realizacja uderza. Podczas kształtowania treści stosunków zatrudnienia niezbędne jest jednak uwzględnienie celów wynikających ze wskazanych wartości, które stanowią fundament życia społecznego. Przez wiele dziesiątków lat rozwój prawa pracy zmierzał ku takiemu ukształtowaniu warunków zatrudnienia, by jak najlepiej służyły one realizacji owych wartości. Ważne jest, by modyfikacje prawa dziś się dokonujące nie zaprzepaściły tego dorobku, który ma wymiar nie tylko ekonomiczny, lecz także społeczny i kulturowy - decyduje o tym, jaka jest treść życia współczesnego człowieka.

By wskazany ostatnio cel zrealizować, postulować należy uznanie za niezbędne każdorazowego dokonywania stosownej oceny tworzonych pod wpływem bieżących potrzeb regulacji prawnych $-z$ wykorzystaniem jako kryterium wskazanej wyżej kategorii wartości. Zważywszy na aspekt techniczny tworzenia aktów prawnych, w pierwszej kolejności ocena taka z natury rzeczy powinna być dokonywana przez podmiot przygotowujący projekt dokumentu. Wymaga- 
nie to daje się urzeczywistnić, jeśli projekt regulacji przygotowywany jest przez osoby reprezentujące środowisko nauki prawa pracy lub polityki społecznej. Taka praktyka pojawia się podczas tworzenia aktów o znaczeniu zasadniczym dla badanej dziedziny prawa, w szczególności projektów kodeksów (ostatnio projektów Kodeksu pracy oraz Kodeksu zbiorowego prawa pracy) lub gruntownej nowelizacji tego typu regulacji (nowelizacje Kodeksu pracy z lat dziewięćdziesiątych ubiegłego wieku). Modyfikacje o mniejszym zakresie (nowelizacje fragmentaryczne), a nawet obszerne akty ustawowe nie będące kodeksami (np. ustawy dotyczące przeciwdziałania bezrobociu) przygotowywane są najczęściej bez udziału przedstawicieli nauki, zwykle przez urzędników odpowiednich ministerstw, a następnie kierowane do legislacji. Częściowa weryfikacja przedmiotowych projektów aktów prawnych w tym zakresie dokonuje się w trakcie obligatoryjnej ich konsultacji z udziałem związków zawodowych i organizacji pracodawców; częściowa - albowiem w tej fazie procesu legislacji możliwość dyskusji jest ograniczona ze względu na krótki czas trwania procedury i zamknięty krąg podmiotów biorących w niej udział. Szersza refleksja, przede wszystkim o charakterze naukowym, nad treścią regulacji prawnych może więc mieć miejsce dopiero po wejściu w życie aktu prawnego. W takiej jednak sytuacji rzadko można liczyć na zmianę ustanowionego już prawa. Jego weryfikacji, również pod wpływem wypowiedzi przedstawicieli nauki, może dokonywać co najwyżej judykatura, która jednakowoż ograniczona jest ścisłym brzemieniem norm prawnych. W określonych sytuacjach modyfikacja stanu normatywnego może być jeszcze dokonana w drodze uchylenia przepisów przez Trybunał Konstytucyjny, który z kolei działa jedynie w ramach uprawnień określonych przez normy Konstytucji - a zważyć trzeba, że w treści Konstytucji nie wszystkie prawa socjalne obywateli zostały wyartykułowane. Polski prawodawca jest co prawda jeszcze determinowany przez obowiązujące standardy wynikające z norm zawartych w konwencjach Międzynarodowej Organizacji Pracy, aktach Rady Europy oraz prawie Unii Europejskiej - lecz w wielu przypadkach ramowy charakter tych regulacji nie gwarantuje dopełnienia interesujących nas celów.

3. Encyklika Laborem exercens Papieża Jana Pawła II z 1981 roku stanowi bez wątpienia dokument, który może być doskonałym punktem odniesienia dla prowadzonych tu rozważań. Za w pełni aktualne należy uznać myśli w niej sformułowane. Dokonane przez Papieża Polaka zdefiniowanie wartości istotnych dla świata pracy nie utraciło swej aktualności mimo upływu czasu oraz zmian politycznych, ekonomicznych i społecznych, które się dokonały.

Zbiór niniejszy zawiera opracowania, które w formie referatów przedstawione zostały podczas Ogólnopolskiej Konferencji Naukowej „W 30-lecie encykliki Jana Pawła II Laborem exercens", poświęconej aksjologicznym problemom prawa pracy. Konferencja odbyła się 9 maja 2011 roku na Wydziale Prawa i Administracji Uniwersytetu Kardynała Stefana Wyszyńskiego w Warszawie. Przedstawione wówczas teksty stały się zaczynem interesującej dyskusji, która zaowocowała 
ideą utrwalenia sformułowanych wówczas stwierdzeń i wniosków w formie publikacji książkowej z myślą, że stanie się ona podstawą do kontynuowania rozpoczętych w ten sposób badań.

Autorami tekstów, poza artykułami prof. dr hab. Anieli Dylus, prof. dr hab. Teresy Wyki oraz autora niniejszych uwag, są młodzi przedstawiciele nauki prawa pracy z polskich ośrodków uniwersyteckich (Warszawa, Łódź, Olsztyn) oraz studenci prawa (z Wydziału Prawa i Administracji Uniwersytetu Kardynała Stefana Wyszyńskiego w Warszawie), którzy w Laborem exercens poszukiwali odniesień dla krytycznej oceny szczegółowych rozwiązań prawnych kształtujących status osób zatrudnionych. Problematyka poszczególnych opracowań jest różnorodna, powiązana zwykle z tematami badań prowadzonych przez ich autorów, które do dnia wydania niniejszej publikacji nierzadko zostały sfinalizowane w postaci pracy magisterskiej lub rozprawy doktorskiej, a których zróżnicowanie wskazuje, jak szerokie i znaczące jest możliwe oddziaływanie Laborem exercens na kształtowanie treści relacji zachodzących pomiędzy podmiotami występującymi na wszystkich płaszczyznach społecznych i prawnych stosunków zatrudnienia. Będące punktem odniesienia dla Jana Pawła II w Laborem exercens wartości stanowią bowiem nieprzemijające kryteria, w świetle których oceniać można stan społecznych stosunków zatrudnienia, ich regulację prawną, ale także sposoby jej interpretacji, a przez to także stosowania tego prawa. Zamieszczone w tym zbiorze opracowania dowodzą zasadności powyższej tezy.

W ocenie autora niniejszego tekstu, na podkreślenie zasługuje inny istotny bardzo kontekst publikacji zamieszczonych opracowań. Otóż, zdecydowana większość Autorów to niemal równolatkowie Laborem exercens, dla których spotkanie z Encykliką zdarzyło się na początku naukowej kariery. To pozwala sformułować przypuszczenie, że opisane w tym dokumencie wartości staną się trwałym elementem tworzonego przez Nich w przyszłości dorobku, zaś sama Laborem exercens będzie żywotnym źródłem dla polskiej nauki prawa pracy. 